\title{
Acute effects of a multinutrient supplement on performance, rate of perceived exertion and markers of catabolism in young resistance trainers practitioners
}

\author{
Marcos Seijo ${ }^{1}$, Nadia Ashrafi ${ }^{2}$, Joshua Smith ${ }^{1}$, Christian Wilkinson ${ }^{1}$, Yue Fu' ${ }^{1}$, Jack Miller ${ }^{1}$, Eneko Larumbe ${ }^{3}$, \\ Fernando Naclerio ${ }^{1 *}$
}

From The Eleventh International Society of Sports Nutrition (ISSN) Conference and Expo

Clearwater Beach, FL, USA. 20-21 June 2014

\section{Background}

The ingestion of a multi-nutrient containing proteins, carbohydrate and creatine has been shown to enhance acute and chronic responses to resistance training, attenuating fatigue and markers of catabolism training after resistance training workouts. The purpose of this study was to investigate the acute effects of a commercially available multinutrient supplement on neuromuscular fatigue, performance, perception of effort and salivary markers of catabolism, during a bout of resistance circuit training session.

\section{Methods}

Twelve recreationally resistance trained young males (age $22 \pm 1.5$ years, body weight $79.4 \pm 10.2 \mathrm{~kg}$, height $181 \pm 0.07 \mathrm{~cm}$ ), volunteered to participate in the study, completing 2 randomised controlled circuit resistance training sessions $(\mathrm{CT})$. Immediately before and after the workout, participants consumed $500 \mathrm{ml}$ of water mixed with $60 \mathrm{~g}$ of a multinutrient supplement (MTN) containing whey proteins, carbohydrate, creatine, HMB and sodium bicarbonate, or maltodextrin (PL). CT involved three rounds of 7 resistance exercises (CM)s, Bench Press, Parallel-Squat, Upright row, Alternate Lunges, Dead Lift, Push-press, Abdominals) followed by $1 \mathrm{~min}$ rest. Participants performed 12 repetitions at 70\% 1RM in each of the exercises with no rest in between (only the time to change from one exercise to the next).

\footnotetext{
* Correspondence: f.j.naclerio@gre.ac.uk

${ }^{1}$ Centre for Sport Science and Human Performance, School of Science,

University of Greenwich, London, United Kingdom

Full list of author information is available at the end of the article
}

Measurements included total $\mathrm{kg}$ lifted per exercise and in the overall workout, the rate of perceived exertion (RPE) determined at the end of each circuit, pre and post blood lactate and markers of neuromuscular fatigue, including Countermovement Jump (CMJ), 1RM Bench Press (1RMBP) and the maximal velocity at $50 \%$ of $1 \mathrm{RM}$ Bench Press (V50\%BP). In addition, salivary markers of catabolism: Free Testosterone $(\mathrm{T})$ and Cortisol $(\mathrm{C})$ were assessed pre, 30min and $60 \mathrm{~min}$ post CT. Consent to publish the results was obtained from all participants.

\section{Results}

No significant differences were observed between the total weight $(\mathrm{kg})$ lifted for the entire $\mathrm{CT}$ or exercise $(P>0.05)$. RPE increased significantly during CT $(\mathrm{p}<0.05)$, but without differences between conditions. Lactate increased significantly from pre to post in both conditions $(p<0.05)$, but without differences between them. Markers of neuromuscular fatigue (CMJ; 1RMBP and $\mathrm{V} 50 \% \mathrm{BP}$ ) significantly decreased from pre to post but without difference between conditions. Salivary C showed a trend, increasing from pre $(7.9 \pm 6.2 \mathrm{nmol} / \mathrm{L})$ to $30 \mathrm{~min}$ post $(18.8 \pm 12.7 \mathrm{nmol} / \mathrm{L}-\mathrm{p}=0.60-)$ and $60 \mathrm{~min}$ post $(18.1 \pm 14.7 \mathrm{nmol} / \mathrm{L}-\mathrm{p}=0.93-)$ in PL while no significant changes or trends were observed for MTN $(10.1 \pm 7.0 \mathrm{Vs} 16.6 \pm 13.9$ and $12.8 \pm 8.5$ respectively). $\mathrm{T}$ showed significant higher values at $30 \mathrm{~min}$ post $(510.1 \pm 124.9 \mathrm{pmol} / \mathrm{L}-\mathrm{p}=0.005-)$ compared to pre $(360.4 \pm 104.6 \mathrm{pmol} / \mathrm{L})$ and a returned to baseline levels at $60 \mathrm{~min}$ post $(402,1 \pm 88,4 \mathrm{pmol} / \mathrm{L})$ for $\mathrm{PL}$, while no changes were observed for MTN. In addition, cortisol showed a 
strong tendency to be higher for PL compared to MTN at $60 \mathrm{~min}$ post $(18.1 \pm 14.7 \mathrm{Vs} 12.8 \pm 8.5 \mathrm{nmol} / \mathrm{L}-\mathrm{p}=0.054-)$. No other differences or trends were observed.

\section{Conclusion}

Ingesting a MTN supplement immediately before and after a circuit resistance training workout, resulted in no impact on performance, attenuate neuromuscular fatigue or perception of effort with respect to the ingestion of only carbohydrate. However, some effect to attenuate the rise in cortisol ( $30 \mathrm{~min}$ and $60 \mathrm{~min}$ post) and testosterone (30 min post) could be produced.

\section{Authors' details}

${ }^{1}$ Centre for Sport Science and Human Performance, School of Science, University of Greenwich, London, United Kingdom. '2Department of Pharmaceutical, Chemical and Environmental Sciences, School of Science, University of Greenwich, London, United Kingdom. ${ }^{3}$ Fundamentals of Motricity and Sports Training Department, School of Sports Sciences, European University of Madrid, Madrid, Spain.

Published: 1 December 2014

doi:10.1186/1550-2783-11-S1-P9

Cite this article as: Seijo et al:: Acute effects of a multinutrient supplement on performance, rate of perceived exertion and markers of catabolism in young resistance trainers practitioners. Journal of the International Society of Sports Nutrition 2014 11(Suppl 1):P9.
Submit your next manuscript to BioMed Central and take full advantage of:

- Convenient online submission

- Thorough peer review

- No space constraints or color figure charges

- Immediate publication on acceptance

- Inclusion in PubMed, CAS, Scopus and Google Scholar

- Research which is freely available for redistribution

Submit your manuscript at www.biomedcentral.com/submit 